\title{
Call to boost research on particulates
}

[WASHINGTON] The United States should launch a long-term research project into the effects on health of airborne particulate matter (PM), according to a committee of the National Research Council (NRC), part of the National Academy of Sciences complex. The committee recommends a 13-year programme costing $\$ 440$ million.

Such a programme, if approved, would be comparable in scope to a comprehensive decade-long acid rain study that was conducted in the 1980s.

The NRC committee, which began work in January and will continue for five years, was asked by Congress to set an agenda for PM research after the Environmental Protection Agency (EPA) enacted controversial new regulations governing particulate emissions last year (see Nature 388, 5; 1997).

Both sides in the bitter regulatory debate agreed that more research is needed. The panel chairman, Jonathan Samet, an epidemiologist at the Johns Hopkins University in Baltimore, Maryland, says the committee's first report, released last month, is the beginning of an attempt to develop a longterm, integrated research plan.

The committee outlined ten research areas it considers high priority for a PM science programme. EPA's current and planned activities are "generally reasonable and potentially useful," it says. But the agency should pay more attention to investigating the relationships between fixed-site outdoor monitoring data and personal exposure to PM. And, rather than initiating epidemiological studies, EPA should concentrate on understanding the mechanisms behind the effects on health attributed to particulates.

The committee was careful not to take a stand on whether EPA's new rules governing particles smaller than 2.5 micrometres are justified on scientific grounds. But it did express concern that the agency is rushing to establish a nationwide network for monitoring PM2.5 without fully considering the needs of researchers.

Monitors for establishing compliance with the law may not be sophisticated enough to characterize the size and chemistry of airborne particles - information required for a broader research programme.

John Bachmann, of EPA's Office of Air Quality Planning and Standards, says that the agency fully intends to use both kinds of monitors, and to consult scientists fully before putting the network in place. His office will hold a workshop next month to solicit the research community's views.

One panel member, Ronald White of the American Lung Association, says the committee simply wanted to emphasize the criti- cal need for research-quality monitoring data. So far, he says, EPA appears to be emphasizing the regulatory role of the monitoring network, and the "health research community is feeling disenfranchised".

The NRC panel also encouraged EPA to accelerate plans to set up several independent university research centres for PM research. Congress designated $\$ 8$ million for this purpose in 1998. But it will take time, according to one EPA source, to review applicants and negotiate contracts. A request for proposals is expected to go out this month.

The NRC committee outlined a 13-year PM research programme ending in 2010, with annual average spending of more than $\$ 50$ million from 1999 to 2003 . Congress almost doubled EPA's request for PM research last year, granting $\$ 49$ million for 1998 . But the agency has asked for only \$29 million in 1999 - partlybecause it was waiting to see what the academy would recommend.

Opinions are divided on whether legislators will approve a long-term increase. One congressional staff member with oversight of EPA's budget says $\$ 50$ million a year is "not very realistic". But another congressional source says that even lawmakers who opposed the new EPA rules favour more research, as they think it will disprove the need for tighter regulation. Tony Reichhardt

\section{US and Japanese scientists in dispute over 'poisoned' radishes}

[токуо] Scientists from the US Food and Drug Administration (FDA) are contesting a claim by Japan's health ministry that radish sprout seeds imported from the United States were to blame for last year's food poisoning outbreak caused by the $0-157$ strain of Escherichia coli. FDA scientists are seeking consultations with ministry officials over the issue.

A report from the ministry's Food Sanitation Investigation Council concludes that an outbreak of food poisoning last March in Aichi and Kanagawa prefectures, which affected 115 people, was caused by eating white radish sprouts grown from contaminated seeds imported from Oregon.

The report says the O-157 E. coli bacterium was not found in the seed sample. But the presence of genetic material linked to vero toxin - a byproduct left by the bacterium - as well as genetic fragments claimed to be unique to O-157 E. coli, were detected.

FDA scientists remain unconvinced, arguing that the test results "do not adequately support the finding that the seeds were contaminated with E. coli O-157". In a statement released by the US Embassy in Tokyo, the FDA points out that the

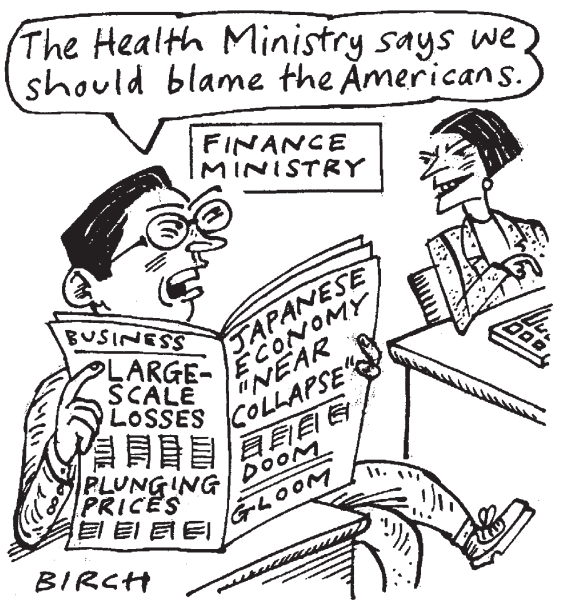

investigation did not involve a direct comparison of O-157 E. coli isolated from patients and samples extracted from the seeds, as would be necessary to conclude that $E$. coli from the seeds was the likely cause of food poisoning.

Explaining why no trace of the bacterium was detected in the seeds under conventional cultivation, ministry officials say that strains of $E$. coli other than O-157 proliferate much faster, suppressing the growth of 0-157 colonies. Despite announcing its intention to enforce mandatory sterilization of radish sprout seeds before cultivation, Japan's Ministry of Agriculture, Fisheries and Forestry is also sceptical about the health ministry's conclusion. "Vero toxins are also found in bacteria other than O-157 E. coli," says a spokesman for the agriculture ministry.

"The test results merely suggest the presence of the bacteria in seed samples; they do not verify the cause of the food poisoning outbreak."

Japanese producers of white radish sprouts say that the health ministry's recent announcement has dealt a new blow to their business. The ministry set off a public health scare in 1996 when it announced that white radish sprouts might be the source of an earlier O-157 food poisoning outbreak in the Osaka area, which affected more than 9,000 people and claimed nine lives (see Nature 382, 567; 1996).

The ministry subsequently came under fire for reaching a hasty and unsubstantiated conclusion. Its announcement forced food distributors to withdraw radish sprouts from shops and restaurants, and drove many farmers to bankruptcy.

Asako Saegusa 